\title{
Influence of Liquidity, Profitability, and Leverage on Company Value
}

\section{(Case Study on Retail Sub-Sector Trading Companies Listed on the Indonesia Stock Exchange 2016-2020 Period)}

\author{
${ }^{*}$ Arti Mardianti ${ }^{1}$, Nanan Sunandar ${ }^{2}$ \\ ${ }^{1}$ Student in Nusa Putra University, Sukabumi, Indonesia \\ ${ }^{2}$ Lecture in Nusa Putra University, Sukabumi, Indonesia \\ ${ }^{*}$ Corresponding author.E-mail: Artiemardianti123@gmail.com
}

\begin{abstract}
This research compares the liquidity ratio to the cost of capital (CR), profitability (ROA), leverage (DER), and corporate value (PBV). The study's population consists of seven retail trade enterprises that are publicly traded on the Indonesian Stock Exchange. We employed purposeful sampling in this study, a method for selecting samples based on predetermined sample criteria relevant to the research objectives. The sample size for this study is 35 people. For analysis and hypothesis testing, regression analysis, partial t-test, and simultaneous test $f$ are utilized. The research revealed a significant link between the variables Liquidity (CR), Profitability (ROA), and Leverage (DER), as well as Firm Value (PBV), where the computed $F$ value surpasses the $F$ table value $(6.229>2.87)$ by a factor of less than 0.05 , or 0.001 . This research compares the liquidity ratio to the cost of capital (CR), profitability (ROA), leverage (DER), and corporate value (PBV). This study sought to determine the effect of liquidity (CR), profitability (ROA), and leverage (DER) on Preferred Business Value (PBV) (a case study on Retail Sub-Sector Companies Trading Listed the Exchange Indonesia for Stack the 2016-2020 period). The author employs an associative analytic approach to do a quantitative analysis. The study's population consists of seven retail trade enterprises that are publicly traded on the Indonesian Stock Exchange.
\end{abstract}

Keywords: Liquidity (CR), Profitability (ROA), Leverage (DER), and Value Company (PBV).

\section{INTRODUCTION}

Investment choices are critical during the current Covid-19 epidemic, as Indonesia's economy has deteriorated significantly, particularly in export and import commerce, affecting stock trading. As a result, the IHSG Composite Stock Price Index has precipitously below the 3,000 thresholds.

The business's worth is based on the assumption of a stable stock price that grows over time [1]. Every business must have a goal, which should be to maximize shareholder wealth and welfare while also enhancing the enterprise's value. Additionally, this term may relate to maximizing current value to convert it to future revenues.

The company's aims and responsibilities are to maximize the value of the business through boosting shareholder profitability and performance. The firm value measures an investor's confidence in a manager's ability to handle the company's resources entrusted to him, and is generally connected with stock prices. The higher the stock price, the more valuable the firm seems to investors, attracting their interest.

Numerous factors, including liquidity, profitability, and leverage, can impact a corporation's value. Businesses that consistently earn substantial profits will naturally attract investors, which benefits investors. Additionally, profitability demonstrates sound business management, which still trusts investors. On the other hand, if a corporation cannot generate profits, investors will be hesitant to invest in its stock [2]. This mistrust is critical because it results in a decline in the stock price, indicating that its value is about to collapse or suffer a significant loss. 
The Liquidity Ratio is projected onto the Current Ratio in this study (CR). The researcher chose the Current Ratio (CR) as a measurement tool because it is a ratio used to determine a business's ability to repay the short-term debt by determining if current assets can cover the existing debt. Profitability is quantified in a percentage of Return on Assets (ROA). The researcher refers to resources as average asset value, and the leverage ratio is projected onto the Debt Equity Ratio (DER).

These financial metrics will affect investment decisions, mainly the company's worth. Investors analyze a company's worth evaluating its prospects and profitability. Thus, the company's value is projected using one of the intrinsic value methodologies for stocks, namely Price Book Value (PBV) [3]. Price Book Value is an analytical approach used by investors to assess a corporation's value. In the comparison, this ratio is chosen as the

The author of the article researched 2021 on eight retail sub-sector trading firms listed on the Indonesian Stock Exchange. Retail sub-sector trade companies are essential to analyze since they were disproportionately impacted by the corporate value loss associated with the Covid-19 outbreak. While retail sales and mass consumption indices recovered, major retail corporations began closing their doors or refocusing their operations in reaction to the impact of the Covid-19 outbreak.

The authors' description indicates that they are interested in "The Effects of Liquidity, Profitability, and Leverage on Firm Value (Case Study on Retail Sub-Sector Trading Companies Listed on the Indonesia Stock Exchange 2016-2020 Period)".

\subsection{Identification of Problems}

The authors offer various identifications based on the previous description of the research's context, including the current ratio, return on asset, debtequity ratio, and those impacting the retail sub-sector trading company's worth on Stack Exchange. Indonesia Stocks Between 2016 and 2020.

\subsection{Formulation of the Problem}

In light of those mentioned above, the research questions are as follows:

1) How does liquidity affect the value of a business?

2) What effect does profitability have on the value of a business?

3) What effect does leverage have on a business's value?

4) How can liquidity, profitability, and leverage impact a business's value?

\subsection{Restricting the Problem}

To control and successfully manage emergent challenges, the researchers limit the independent variables liquidity and profitability to the Current Ratio (CR) and Return on Assets. Leverage is established solely by the Debt to Equity Ratio (DER). This directly affects the company's worth via the Price to Book Value ratio (PBV),

\section{LITERATURE REVIEW}

\subsection{The Value of the Company}

To control and successfully manage emergent challenges, the researchers limit the independent variables liquidity and profitability to the Current Ratio (CR) and ROA, respectively ROA. Leverage is calculated solely based on the debt to equity ratio. This directly affects the company's worth via the Price to Book Value ratio (PBV).

\subsection{Company Value Indicator}

The author utilized the indicator Price to Book Value to determine the company's value in this study (PBV). The Price to Book Value ratio indicates if a traded stick's price is greater than or less than the Book Value. The greater the PBV, the more optimistic investors are about the firm's prospects [6]. The following formula is used to determine the Price to Book Value (PBV):

Price of Book Value $=\frac{\text { Share Cost }}{\text { Book Value }} \times 100 \%$

\subsection{Liquidity Ratio Indicator}

The liquidity ratio is a ratio that indicates a business's capacity to meet its short-term obligations. The liquidity ratio sometimes referred to as the DER, is a financial measure used to assess a business's capacity to repay short-term borrowing commitments as they mature [1].

The Recent Statistic is a financial ratio that is used to determine a business's capacity to meet immediate commitments or payments due upon invoicing [7]. The authors calculate the liquidity ratio using the current indicator ratio in this study. The following formula is used to calculate the current ratio:

$$
\text { Curret Ratio }=\frac{\text { Curreny Asset }}{\text { Current Liabilities }} \times 100 \%
$$

\subsection{Profitability}

Profitability is a metric used to determine how well a firm earns income. This demonstrates the business's revenue maximization efficiency. [2]. 
In this study, the profitability ratio is evaluated using the Return on Assets (ROA) metric to determine the contribution of assets to net income. The following formula is used to determine the return on assets (ROA):

Return On Assets $=\frac{\text { Net Profit }}{\text { Total Assets }} \times 100 \%$

\subsection{Leverage}

Leverage ratios reveal how much debt a corporation owes to finance its activities. The increase in debt will require the firm to make interest payments.

The author calculates the leverage ratio in this study using the Debt Equity Ratio (DER) indicator. The DER is a leverage ratio (solvability) that reflects a company's external and internal capital allocation. The DER is calculated using the following formula:

Debt to Equity Ratio $=\frac{\text { Total Debt }}{\text { Equity }} \times 100 \%$

\subsection{Framework of Thinking}

To emphasize the vital significance of understanding liquidity, profitability, and leverage in creating value, the authors illustrate their rationale using the following image from the study framework:

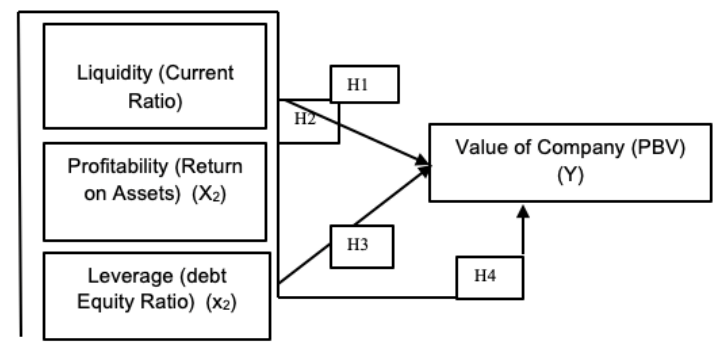

Figure 1. Model Research

\subsection{Research Hypothesis}

The following research hypothesis is formed based on the initial framework:

- H1 Between 2016 and 2020, liquidity will affect the value of Retail Sub-Sector Trading Listed companies on the Indonesian Stock Exchange.

- Profitability in the $\mathrm{H} 2$ sector affects the value of Retail Sub-Sector Trading Listed companies on the Indonesian Stock Exchange between 2016 and 2020.

- H3 From 2016 to 2020, the impact of leverage on the value of firms listed on the Indonesian Stock Exchange in the Retail Sub-Sector Trading Companies.
- H4 Between 2016 and 2020, the impact of liquidity, prudential management, and leverage on the value of Retail Sub-Sector Trading Listed companies on the Indonesian Stock Exchange.

\section{RESEARCH METHODS}

\subsection{Research Design}

Quantitative research is positivist in nature since it examines specific populations or samples, collects data using research procedures, and analyzes statistical data to evaluate pre-established hypotheses [11], [12]. Due to the vast number of variables examined and the objective of providing an overview of their connections, the authors employ quantitative methods with an associative analytical approach in this study [9], [10]. The dependent variable, the independent variable, and the intervening variable were all used in this investigation.

\subsection{Population and Sample}

Indonesia Stack Exchange was a five-year listing on the exchange, commencing in 2016 and concluding in 2020. The financial records of Retailers Sub-Sector Trading Companies were used as the population for this study. Purposive sampling was used to choose the sample for this study. We used the following criterion:

Between 2016 and 2020, Retail Sub-Sector Trading Companies will be listed on Indonesia's Stack Exchange:

1) Disseminate annual financial accounts and financial statements for 2016-2020.

2) The business generates a profit.

3) The company's listing on the Indonesian Stock Exchange has been preserved.

The following retail sub-sector trade businesses were sampled for this study:

Table 1. The retail sub-sector trade businesses

\begin{tabular}{|c|c|l|}
\hline No & $\begin{array}{c}\text { Company } \\
\text { Code }\end{array}$ & \multicolumn{1}{|c|}{ Company Name } \\
\hline 1 & ACES & PT ACE Hardware Indonesia Tbk \\
\hline 2 & MPPA & PT Matahari Putra Prima Tbk \\
\hline 3 & HERO & PT Hero Supermarket Tbk \\
\hline 4 & CSÁP & PT Catur Sentosa AdipranaTbk \\
\hline 5 & AMRT & PT Sumber AlfariaT rijayaTbk \\
\hline 6 & LPPF & PT Matahari Department Store Tbk \\
\hline 7 & MIDI & PT Midi Utama Indonesia Tbk \\
\hline
\end{tabular}




\subsection{Types and Techniques of Data Collection}

This analysis gathered data from secondary sources, most notably the farm of publicly-traded businesses' annual reports from 2016 to 2020. The data source is each company's publishing of financial statements on the Indonesia Stock Exchange, which may be obtained via the Indonesia Stock Exchange.

\subsection{Control variables}

\subsubsection{Analysis Prerequisite Test}

The classical hypothesis test is utilized as a precondition for this analysis since it is used to assess the viability of a regression model prior to doing the regression analysis [11]. This article used the Data Normality Test, the Heteroscedasticity Test, and the Multicollinearity Test.

\subsubsection{Analysis Techniques and Hypothesis Testing Multiple Linear Regression Analysis}

Multiple linear regression analysis is used in this approach using the SPSS assistance program version 24.0 [13].

\subsubsection{Analysis Determination}

The coefficient of determination (R2), as defined by [3, indicates how well a model accounts for variance in variables. The coefficient of determination is a value between 0 and 1 [14]. R2 is a tiny number, implying that the dependent variables have a limited capacity. On the other hand, a value close to an independent variable contains almost all of the information necessary to calculate the dependent predictor variables. This research presents the revised $\mathrm{R}$ Square value. This is because adjusted $\mathrm{R}$ Square is more valid than $\mathrm{R}$ Square since the standard error is eliminated.

\subsection{Hypothesis Testing}

Hypothesis testing is a strategy for identifying a temporary solution to a problem that is still considered a hypothesis due to lack of evidence [4]. Utilization of the SPSS 24.0 software (Statistical Product and Service Solution).

\subsection{T-Test (Partial Test)}

The partial test determines the significance of the variable l's effect on the variable. The partial test compares the T-value to the T-table's value. The steps for doing the t-test are as follows:
1) Formulate the hypothesis and test both the null (H0) and alternative (Ha) hypotheses:

- H0: b1 equals 0. Liquidity has had little influence on the value of retail firms listed between 2016 and 2020 .

- Ha: b1 equals 0. Between 2016 and 2020, liquidity influences the value of retail firms listed in 2016 and 2020.

- H0: b2 equals 0. Between 2016 and 2020, profitability had minimal influence on the firm value of retail firms listed 20162020.

- Ha: b2 = 0 Profitability influences the value of retail firms listed between 2016 and 2020.

- H0: b3 equals 0 Leverage affects the value of retail firms listed between 2016 and 2020.

2) The natural level is equal to 0,05 , the value of the $\mathrm{T}$ count is compared to the $\mathrm{T}$ table, and the following conditions are met:

- If $\mathrm{T}$ count $>\mathrm{T}$ table, Ho is accepted while $\mathrm{Ha}$ is refused. - If $\mathrm{T}$ count $>\mathrm{T}$ table, Ho is accepted while $\mathrm{Ha}$ is rejected.

\subsection{F Test}

The ANOVA (Analysis of Variance) section details the ANOVA (Analysis of Variance) procedure. A statistical hypothesis is advanced [5] as follows:

- H0: b1 = 0 Between 2016 and 2020, Liquidity, Profitability, and leverage all affect firm value.

Calculate the significance level (significant), in this case, $=0.5$. Additionally, given the following conditions, the $\mathrm{F}$ count hypothesis is compared to the F table:

- If the $\mathrm{F}$ value is greater than the value specified in the F table, $\mathrm{HO}$ is rejected; nevertheless, Ha is allowed.

- If the F table contains F, H0 is permitted but not $\mathrm{Ha}$. The section on ANOVA (Analysis of Variance) processing provides detailed instructions on conducting the analysis (Analysis of Variance). The following statistical hypothesis [5] is proposed:

- H0: b1 equals 0 Between 2016 and 2020, liquidity, profitability, and leverage influence the value. 


\section{RESULT AND DISCUSSION}

\subsection{Research Results}

\subsubsection{Description of Research Variables}

The variables liquidity (CR), profitability (ROA), and leverage (DER) were characterized as independent variables, while firm value (PBV) was classed as either a dependent or a dependent variable [6]. Between 2016 and 2020.

According to the author's inquiry, there was a difference between theory and practice at PT. ACE Hardware Indonesia Tbk, as evidenced by four different events and concepts. In 2018 and 2019, we used the current ratio, while in 2017 and 2020, we used the debt-equity ratio (DER). In 2018 and 2019, the company's current ratio decreased. In 2018, the firm's current ratio dropped by 0.38 times and 0.88 times in 2019. In comparison, in 2018 and 2019, the firm's worth grew. Additionally, the company's Debt Equity Ratio (DER) increased by 0.01 point in 2017 despite a 0.58 point decline in the company's value, and by 0.01 point in 2016 despite a 0.43 point increase in the company's value.

PT Matahari Putra Prima Tbk's debt-toequity ratio (DER) might have been an inconsistency. Between 2016 and 2020, the value of PT Matahari Putra Prima Tbk decreased. This contrasts sharply with the company's rising debt-toequity ratio (DER). This means that as PT Matahari Putra Prima Tbk Debt's Equity Ratio (DER) increases, the company's value diminishes.

Gap phenomena may be classified into four basic types. This company is called PT Hero Supermarket Tbk. Between 2017 and 2019, the business's debt increased by 0.01 times, while the firm's value fell. The company's worth fell by 0.51 times in 2017 and 0.56 times in 2019. Return On Assets climbed by 0.95 percent in 2018 but then fell by 0.77 percent in 2020. By contrast, the firm's value declined by 0.20 in 2017 but climbed by 0.32 in 2020 .

Six gap phenomena occur at PT Catur Sentosa Adiprana Tbk. Debt Equity Ratio (DER) climbed by 0.27 points in 2019, while the company's value decreased by 0.24 points. In 2017, the company's current ratio increased by 0.17 points, but its value declined by 0.96 points. In 2018, the business's current ratio decreased by 0.11 , while its debt-to-equity ratio decreased by 0.07 . By comparison, the value of the business has climbed 0.39 times. By 2020, the firm's current ratio will have grown 2.98 times, while its return on assets will have climbed 6.86 percent. On the other side, the company's value would have fallen by 0.39 times.
Five gap phenomena occur in PT Sumber Alfaria TrijayaTbk. During 2018 and 2019, the corporation's current ratio was insufficient. In 2018, the Current Ratio increased by 0.04 points, whereas it increased by 0.07 points in 2015 . By contrast, the firm's value dropped by 0.11 in 2018 and 0.36 in 2019. In 2017 and 2018, the company's Debt Equity Ratio (DER) grew by 0.09 and 0.10 times, respectively. This stands in stark contrast to the company's declining worth in 2017 and 2018. While Return on Assets improved by 1.32 percent in 2017, the firm's value decreased by 0.11 times in 2018 .

Six gap phenomena occur at PT Matahari Department Store Tbk. Between 2018 and 2020, the corporation's current ratio and return on assets increased yearly. Both the current ratio and return on assets of the firm decreased in 2017. In 2017, its current ratio dropped by 1.05 times, while its return on assets reduced by 8.39 percent. However, the company's value climbed by 1.38 times. In 2018, the Current Ratio grew by 0.03 percent, while the Return on Assets improved by 2.07 percent, compared to a 1.35 percent decline in the company's value. It boosted its debt-to-total-assets ratio by 0.46 percentage points in 2019 while decreasing the value of its assets by 1.35 percentage points. By 2020, the business's current ratio will have increased to 0.27 times its current value, while its value will have decreased to 0.36 times its current value.

Six gaps characterize PT Midi Utama Indonesia Tbk. In 2017, the Debt Equity Ratio (DER) increased to 0.51 times enterprise value from 0.09 times in 2016. The Current Ratio was reduced by 0.02 in 2018, and the Debt Equity Ratio (DER) decreased by 0.49 , while the market capitalization increased by 0.35 . The current ratio gained 0.06 points in 2019 , the debt-equity ratio increased 0.26 points, and the company's worth decreased 0.69 points in 2019. By 2020, the current ratio of the corporation will have decreased to 0.06 times its current value, while its value will have increased to 0.6 times its current value.

\subsection{Analysis Prerequisite Test Results}

\subsubsection{Normality Test}

The normality test was conducted using the One-Sample Kolmogorov-Smirnov approach, which compares the KS test results to a predefined threshold of significance. The following table presents the normality test results on the two variables.: 
Table 2. Normality Test

One-Sample Kolmogorov-Smirnov Test

\begin{tabular}{llr} 
& & \multicolumn{1}{c}{$\begin{array}{c}\text { Unstandarded } \\
\text { Residual }\end{array}$} \\
\hline $\mathrm{N}$ & & 35 \\
\hline Normal Paramters $^{\mathrm{a}, \mathrm{b}}$ & Mean &, 00000000 \\
\cline { 2 - 3 } & $\begin{array}{l}\text { Std. } \\
\text { Deviatian }\end{array}$ &, 61727262 \\
\hline Mast Extreme & Absalute &, 131 \\
\cline { 2 - 3 } Differences & Pdssitive &, 131 \\
\cline { 2 - 3 } & Negqtive &,- 089 \\
\hline Test Statistic & &, 131 \\
\hline Asympy. Sig. (2-tailed) & &, $134^{\mathrm{c}, \mathrm{d}}$ \\
\hline
\end{tabular}

According to the SPSS output calculation in the table above, the normality test results for the three research variables indicate that Asymp is significant. The Kolmogorov-Smirnov normalcy test indicates that Sig (2-Tailed) is greater than or equal to $0.134>0.05$. According to the criteria outlined above, one may assert that the distribution is normal and that the regression model's assumptions or requirements for normality are fulfilled.

\subsubsection{Heteroscedasticity Test}

A homoscedastic or non-occurring grad regression model is a grad regression model. The table below summarizes the heteroscedasticity test results:

Table 3. Heteroscedasticity Test

\begin{tabular}{|c|l|c|}
\hline \multicolumn{2}{|c|}{ Model } & Sig. \\
\hline \multirow{4}{*}{1} & (Constant) &, 233 \\
\cline { 2 - 3 } & Liquidity (CR) &, 619 \\
\cline { 2 - 3 } & Profitability (ROA) &, 783 \\
\cline { 2 - 3 } & Leverage (DER) &, 249 \\
\hline
\end{tabular}

Dependent Variable: ABS_RES

According to the table above, the Gelsjer test reveals that each variable has a significant value larger than 0.05 , namely (X1) Liquidity (CR) of 0.619 , (X2) Profitability (ROA) of 0.783 , and (X3) Leverage (DER) of 0.249 , showing that this research is not heteroscedastic. As a result, the structure of the independent variables is homoscedastic.

\subsubsection{Multicollinearity Test}

Collinearity is discovered by comparing the VIF and tolerance values to the test criteria. There is no multicollinearity if the VIF is between 1 and 10 with a tolerance value smaller than 1 . The table below summarizes the results of data processing using SPSS 24.0's multicollinearity test:
Table 4. Multicollinearity Test Results

\begin{tabular}{|c|c|c|c|}
\hline \multicolumn{2}{|c|}{ Model } & \multicolumn{2}{c|}{ Collinearity Statistics } \\
\cline { 3 - 4 } & Tolerance & VIF \\
\hline \multirow{3}{*}{1} & (Constant) & & \\
\cline { 2 - 4 } & Liquidity (CR) &, 545 & 1,834 \\
\cline { 2 - 4 } & Profitability (ROA) &, 572 & 1,750 \\
\cline { 2 - 4 } & Leverage (DER) &, 493 & 2,029 \\
\hline
\end{tabular}

Dependent Variable: Firm Value (PBV)

According to the test results in the table above, all independent variables have a Tolerance larger value than 0.10 , specifically the Liquidity variable (CR) of 0.545 , the Profitability (ROA) variable of 0.572 , and the Leverage variable (DER) of 0.493, while the Liquidity variable (CR) of 1.834, the Profitability (ROA) variable of 1.750 , and the Leverage (DER) variable of 2.029. Thus, this model does not exhibit multicollinearity, and the independent variables demonstrate a substantial relationship or correlation.

\subsubsection{Linearity Test}

To verify that the model specification is a linear function, perform the following partial $\mathrm{F}$ test on each independent variable concerning the dependent variable:

The following table presents the results of SPSS 24.0 data processing for the variable (X1) vs. (Y) linearity test:

Table 5. Result Firm Value (PBV) * Liquidity (CR)

\begin{tabular}{|c|c|c|c|}
\hline & & & Sig. \\
\hline \multirow{5}{*}{$\begin{array}{l}\text { Firm } \\
\text { Value } \\
(\mathrm{PBV})^{*} \\
\text { Liquidit } \\
\text { y (CR) }\end{array}$} & \multirow{3}{*}{$\begin{array}{l}\text { Between } \\
\text { Groups }\end{array}$} & (Combined) &, 001 \\
\hline & & Linearity & ,002 \\
\hline & & $\begin{array}{l}\text { Deviation } \\
\text { from } \\
\text { Linearity }\end{array}$ & 291 \\
\hline & \multicolumn{2}{|c|}{ Within Groups } & \\
\hline & \multicolumn{2}{|c|}{ Total } & \\
\hline
\end{tabular}

From the table above, the linearity test yields a significant level (Linearity) of 0.002 . The linearity test findings have a significant value less than 0.05 , specifically 0.0020 .05 , and a significance value (Deviation from Linearity) of $0.291>0.05$. That example, the variables (X1) and (Y) suggest that the study variable is linear or that there is a linear connection. As a result, the variable (X1) has a beneficial influence on the variable (X2) (Y). 
The table below summarizes the findings of SPSS 24.0 data processing on the linear test of the variable (X2) against (Y):

Table 6. Result Firm Value (PBV) * Profitability (ROA)

\begin{tabular}{|c|c|c|c|}
\hline & & & Sig. \\
\hline \multirow{5}{*}{$\begin{array}{c}\text { Firm } \\
\text { Value } \\
(\text { PBV) * } \\
\text { Profitabilit } \\
\text { y (ROA) }\end{array}$} & \multirow{3}{*}{$\begin{array}{l}\text { Between } \\
\text { Groups }\end{array}$} & $\begin{array}{c}\text { (Combined } \\
\text { ) }\end{array}$ & ,001 \\
\hline & & Linearity & ,001 \\
\hline & & $\begin{array}{l}\text { Deviation } \\
\text { from } \\
\text { Linearity }\end{array}$ &, 350 \\
\hline & \multicolumn{2}{|c|}{ Within Groups } & \\
\hline & \multicolumn{2}{|c|}{ Total } & \\
\hline
\end{tabular}

The linearity test yielded a significance level of 0.001 (Linearity). The results of this linearity test have a significance value less than 0.05 , precisely 0.0010 .05 , and a significance value (Deviation from Linearity) of $0.350>0.05$, indicating that the variables (X2) and (Y) show that the research variable is linear or that there is a linear connection. As a result, the variable (X2) has a beneficial influence on the variable (X1) (Y).

The table below summarizes the findings of SPSS 24.0 data processing for the linearity test of the variable (X3) against (Y):

Table 7. Data processing of the linearity test of the variable

\begin{tabular}{|c|c|c|c|}
\hline & & & Sig. \\
\hline \multirow{2}{*}{$\begin{array}{c}\text { Firm Value } \\
\text { (PBV) }\end{array}$} & \multirow{3}{*}{$\begin{array}{l}\text { Between } \\
\text { Groups }\end{array}$} & (Combined) &, 001 \\
\hline & & Linearity & ,001 \\
\hline $\begin{array}{l}\text { Leverage } \\
\text { (DER) }\end{array}$ & & $\begin{array}{c}\text { Deviation } \\
\text { from Linearity }\end{array}$ & ,344 \\
\hline
\end{tabular}

As seen in the preceding table, the linearity test produces a significant level (Linearity) of 0.001 . The significant result for this linearity test is less than 0.05 , precisely 0.0010 .05 , and the significance value for Deviation from Linearity is $0.344>0.05$, suggesting that the variables (X3) and (Y) demonstrate that the research variable is linear or has a linear relationship. As a result, the variable (X3) has a favorable effect on the variable (Y).

\subsection{Results of Analysis Techniques and Hypothesis Testing}

\subsubsection{Multiple Linear Regression Analysis}

SPSS version 24.0 for Windows is used to complete the computation. The following table highlights the data processing results.

Table 8. Multiple Linear Regression Analysis Results

\begin{tabular}{|c|l|c|c|}
\hline \multicolumn{2}{|c|}{ Model } & \multicolumn{2}{c|}{$\begin{array}{c}\text { Unstandardized } \\
\text { Coefficients }\end{array}$} \\
\cline { 3 - 4 } \multicolumn{2}{|c|}{1} & B & Std. Error \\
\hline \multirow{3}{*}{1} & (Constant) & 6,460 & 4,373 \\
\cline { 2 - 4 } & Liquidity (CR) &, 483 &, 067 \\
\cline { 2 - 4 } & Profitability (ROA) &, 376 &, 027 \\
\cline { 2 - 4 } & Leverage (DER) &, 464 &, 191 \\
\hline
\end{tabular}

It may be studied using the formula: $\mathrm{Y}=6,460$ $+0,483 \mathrm{X} 1+0,376 \mathrm{X} 2+0,464 \mathrm{X} 3$

The coefficients of multiple linear regression from the above equation have the following values:

1) The constant 6.460 indicates that the variables Liquidity (CR), Profitability (ROA), and Leverage (DER) are all equal to 6.460.

2) The coefficient (1) is 0.483 in the positive direction. This implies that for every unit increase in the Liquidity (CR) variable, the Firm Value (PBV) increases by 0.483 units, assuming that all other variables remain constant.

3) The coefficient (2) has a value of 0.376, which is positive. This means that for every rise in the Profitability (ROA) variable, the Flr Value (PBV) grows by 0.376 , assuming all other variables remain constant.

4) (3) has a positive coefficient of 0.464 . If all other variables remain constant, while the Leverage (DER) variable is increased by one, the Firm Value (PBV) increases by 0.464 .

\subsubsection{Coefficient of Determination}

The following table seen from the results of the coefficient of determination test that have been adjusted by Adj $\mathrm{R}^{2}$ research, which can be seen in the table below: 
Table 9. Coefficient of Determination

\begin{tabular}{ll|r|r|r} 
& & \multicolumn{3}{c}{ Model Summary } \\
& & $\mathrm{R}$ & Adjusted R & Std. Error of \\
Model & $\mathrm{R}$ & Square & Square & the Estimate \\
\hline 1 &, $639^{a}$ &, 408 &, 340 &, 64645 \\
\hline
\end{tabular}

a. Predictors: (Constant), Leverage (DER), Profitabilitas

$(\mathrm{ROA})$, Likuiditas (CR)

According to the table above, the coefficient of determination, or Adjusted R Square, is 0.340, suggesting that the Liquidity (CR), Profitability (ROA), and Leverage (DER) variables all have a 34.0 percent effect on the Company Value (PBV). By contrast, 66.0 percent of the remaining data is impacted by other independent factors.

\subsubsection{Statistical Hypothesis Test}

To determine the significance of each variable's influence, the Statistical Hypothesis Test is utilized, precisely the partial t-test and the simultaneous Ftest:

\section{1) T-Test}

The test is a partial test of independent variable effect used to evaluate the significance of one independent variable's influence on another independent variable when the other factors are fixed and independent. According to the data processing findings, the t-count for each variable is as follows:

Table 10. T-Test Results

\begin{tabular}{|c|l|r|r|}
\hline \multicolumn{2}{|c|}{ Model } & \multicolumn{1}{c|}{$t$} & \multicolumn{1}{c|}{ Sig. } \\
\hline \multirow{3}{*}{1} & (Constant) & 7,232 &, 001 \\
\cline { 2 - 4 } & Liqudity (CR) & 5,237 &, 002 \\
\cline { 2 - 4 } & Profitability (ROA) & 4,869 &, 001 \\
\cline { 2 - 4 } & Leverage (DER) & 4,422 &, 001 \\
\hline
\end{tabular}

The results of the above t-test calculations can be explained in the following explanation:

- H1: The Liquidity (CR) Effect on Firm Value (PBV). In compared to the t-table at $=0.05$, the findings of the Multiple Linear Regression Analysis above indicate that tcount > t-table and sig $=0.05$, i.e. $5.237>$ 1.692 and 0.002 .5 . This confirms the validity of the author's hypothesis that a positive and substantial relationship exists between the Liquidity variable (CR) and
Firm Value (PBV). As a result, the findings support hypothesis 1. (accepted)

- H2: The Profitability (ROA) Effect on Firm Value (PBV). In comparison to the t-table at $=.5$, the Multiple Linear Regression Analysis above suggests that t-count $>\mathrm{t}$ table and sig $>0.5$, which equate to $4.869>$ 1.692 and 0.001 .5 , respectively. This proves the author's hypothesis is correct, namely that the variables Profitability and Firm Value have a positive and statistically significant relationship (PBV). As a result, the data favors hypothesis 2 . (accepted).

- H3: Leverage's Effect on Firm Value (PBV). In compared to the t-table at $=0.05$, the findings of the Multiple Linear Regression Analysis above indicate that tcount $>\mathrm{t}$-table and sig $=0.05$, i.e. $4.422>$ 1.692 and 0.001.5. This substantiates the author's contention that the Leverage variable has a considerable positive effect on Firm Value (PBV). As a result, the data favors hypothesis 3 . (accepted)

2) F Test (Simultaneous Test)

- H4: simultaneously, the effect (CR), profitability (ROA), and leverage (DER) on the company's value (PBV). In this study, the $\mathrm{f}$ test is utilized at a $95 \%$ confidence level, or $5 \%$, with the numerator k-1 degrees of freedom equal to 2 and the denominator $\mathrm{n} \mathrm{k-1}$ degrees of freedom equal to 92 , or maybe expressed as f 0.0 , dl $(2,74)$. The following table summarizes the results of SPSS data processing using the f test:

Table 11. F-Test Result

\begin{tabular}{|l|l|l|l|}
\hline \multicolumn{2}{|l|}{ Model } & F & Sig. \\
\hline 1 & Regression & 6,229 &, $001^{\mathrm{b}}$ \\
\hline
\end{tabular}

a. Dependent Variable: Corporate Value (PBV)

b. Predictors: (Constant), Leverage (DER),

Profitability (ROA), Likuidity (CR)

As seen in the SPSS output data table above, the computed $\mathrm{F}$ value is more than the $\mathrm{F}$ table value $(6.229>2.87)$ with a significance level of less than 0.05 , or 0.001 . When the variables Liquidity (CR), Profitability (ROA), and Leverage (DER) are studied simultaneously in regression analysis, they all have a substantial effect on the Flr Value (PBV). Consequently, hypothesis number four $\mathrm{Ho}$ is rejected, but hypothesis number four Ha is approved. 


\section{CONCLUSION}

Based on the results of the data analysis and discussion described above, the following conclusions can be drawn:

1) The results of the first hypothesis show that the liquidity variable (CR) influences the Firm Value (PBV) of Retail Sub-Sector Trading Listed companies on the Indonesian Stock Exchange.

2) The second hypothesis test establishes that profitability (ROA) influences the firm value (PBV) of retail sub-sector trading listed companies on the Indonesian Stock Exchange.

3) The third hypothesis test establishes that leverage (DER) affects the Firm Value (PBV) of SubSector Trading Listed Firms on the Indonesian Stack Exchange.

4) When the four factors Liquidity (CR), Profitability (ROA), and Leverage (DER) are combined, the results indicate that they all have a substantial effect on Firm Value (PBV) in SubSector Trading Companies listed on the Indonesian Stock Exchange

\section{REFERENCES}

[1] A. Halim and B. Supomo, Management Accounting. Yogyakarta: BPFE, 2016.

[2] V. W. Sujarweni, Management Accounting. Yogyakarta: New Library Press, 2017.

[3] James O. Gill, Financial Ratios. Jakarta: Salemba Empat, 2017.

[4] A. Sartono, Financial Managment: Theary and Application, Fourth. Yogyakarta: BPFE, 2017.

[5] B. Riyanto, Fundamentals of Corporate Expenditure, Fourth. Yogyakarta: BPFE, 2017.

[6] I. N. Fatchan and R. Trisnawati, "The effect of good corporate governance on the relationship between sustainability report and firm value (empirical study of publicly listed companies in Indonesia for 20142015," Indones. Account. Financ. Res., vol. 1, no. 1, pp. 25-35, 2018.

[7] Hery, Financial Statement Analysis. Jakarta: PT. Gramedia Widiasarana Indonesia, 2016.
[8] Cashmere, Analysis of Financial Statements. Jakarta: Rajawali Press, 2017.

[9] J. Supranto, Application Research Methods in Marketing, Seventh Re. Yogyakarta: Rineka Cipta, 2017.

[10] Prayitno, Quantitative Research Methods in Education and Guidance and Counseling. Jakarta: Raja Graphic Persada, 2017.

[11] Sugiyono, Qualltatlve Quantitatlve Ressearch Metthods and R\&D. Bandung: Alfabeta, 2017.

[12] Sujianto, Quantitative Method: Theory and Application. Yogyakarta: YKPN, 2016.

[13] Munawir, Analysis of Financial Statements, 4th ed. Yogyakarta: Liberty, 2017.

[14] I. Ghozali, Application of Multivariate Analysis with IBM SPSS 23. Semarang, 2016.

[15] N. Sudjana, Statistical Methods. Bandung: Tarsito Publishers, 2016.

[16] I. Fahmi, Financial Statement Analysis. Bandung: Alfabeta, 2017. 